\title{
PENGENALAN IRIS MENGGUNAKAN FITUR LOCAL BINARY PATTERN DAN RBF CLASSIFIER
}

\author{
Muhammad Ezar Al Rivan \\ Teknik Informatika \\ STMIK Global Informatika MDP \\ Email: meedzhar@mdp.ac.id \\ Siska Devella \\ Teknik Informatika \\ STMIK Global Informatika MDP \\ Email: siskadevella@mdp.ac.id
}

\begin{abstract}
ABSTRAK
Iris merupakan bagian dari mata yang memiliki keunikan. Keunikan pada iris ini menjadi alasan iris digunakan sebagai identitas seperti sidik jari,dan suara. Dibandingkan dengan sidik jari, iris memiliki kelebihan karena letak iris yang lebih terlindungi. Setiap individu memiliki pola iris yang berbeda dan pembentukan pola iris tidak berhubungan dengan faktor genetik individu, sehingga iris merupakan biometrik yang memiliki keunikan yang tinggi dan sulitnya untuk dilakukan pemalsuan biometrik. Identifikasi atau pengenalan iris dilakukan dengan menggunakan citra iris. Pada penelitian ini citra iris akan dilakukan tahap praproses yaitu dengan menghilangkan noise seperti bulu dan kelopak mata, yang kemudian hasil praproses citra iris dilakukan ekstraksi fitur menggunakan algoritma Local Binary Pattern (LBP). Setelah proses ekstraksi fitur dilakukan, proses selanjutnya adalah melakukan pelatihan menggunakan Radial Basis Function (RBF). Setelah proses pelatihan, model RBF diuji dengan data iris yang berbeda. Akurasi tertinggi yang dicapai pada pengenalan iris menggunakan fitur LBP dan RBF yaitu 83,33\%.
\end{abstract}

Kata kunci: pengenalan; iris; LBP; RBF.

\section{ABSTRACT}

Iris are unique part of eyes. Iris uniqueness cause iris uses as identity like fingerprint and voice. Compare with fingerprint, iris has advantages based on iris location more protected than fingerprint. Each human has different iris pattern and this pattern not related to genetic factor so iris has very uniqe and hard to fake. Iris identification or recognition conduct based on iris image. In this research, preprocessing step conduct to remove noise like hair and eyelid then feature extraction conducted to iris image using Local Binary Pattern (LBP). After feature extraction done, next process is training using Radial Basis Function (RBF). The next step is testing RBF model using different iris data. The highest accuracy in iris recognition using LBP feature dan RBF classifier is $83,33 \%$

Keywords: recognition; iris; $L B P ; R B F$.

\section{PENDAHULUAN}

Komputer merupakan sarana yang dapat digunakan untuk mempermudah pekerjaan manusia. Biometri merupakan sistem yang berkaitan dengan komputer. Biometrik dapat diartikan sebagai sistem yang menggunakan bagian tubuh manusia untuk identitas pribadi seseorang. Dalam sistem biomterik bagian tubuh manusia digunakan karena sifatnya yang unik. Perubahan fisik sebagai pengenal dapat berubah sehingga dapat menyebabkan kesulitan dalam penggunaannya. Biometrik yang umum digunakan yaitu fingerprint. Fingerprint memilki kelemahan karena berada diluar tubuh yang rentan terkena luka sehingga fingerprint tidak dapat digunakan. Dengan kemajuan teknologi, fingerprint juga dapat diduplikasi sehingga fingerprint kurang aman digunakan. Oleh karena itu dibutuhkan suatu sistem biometrik yang tahan akan perubahan dan unik. Biometrik lain yang memiliki kriteria tersebut adalah sistem identifikasi pengenalan iris.

Iris atau yang biasa dikenal dengan selaput pelangi terletak di antara kornea mata dan lensa mata serta berfungsi sebagai pengontrol intensitas atau jumlah cahaya yang masuk dengan melakukan pembesaran dan pengecilan pupil. Iris pada setiap manusia berbeda-beda dan memiliki kestabilan sepanjang hidup terkecuali jika terjadi kecelakaan yang menyebabkan kerusakan pada iris [1]. Meskipun sama fungsinya dengan sidik jari, iris memiliki kelebihan tersendiri dalam proses pengenalan di karenakan letaknya di dalam mata dan dilindungi oleh kelopak mata serta memiliki pola yang unik dikarenakan tekstur yang dimiliki iris seperti korona, bintik-bintik, garis dan kerutan. Bahkan anak yang kembar identik sekalipun juga memiliki pola iris yang berbeda. 
Peneliti sebelumnya melakukan comparative study terkait dengan pengenalan iris [2]. Pada penelitian ini terdapat beberapa metode yang digunakan untuk pengenalan iris baik untuk metode ekstraksi fitur dan metode pengenalan. Penelitian yang dilakukan oleh [3] metode yang digunakan untuk ekstraksi fitur yaitu Gray Level Cooccurence Matrix (GLCM), Local Binary Pattern (LBP) dan Gabor Wavelet sedangkan metode pengenalan yang digunakan yaitu Support Vector Machine (SVM), hasil pengujian menunjukkan bahwa metode LBP memberikan persentase correct classification yang baik yaitu 92,6\% jika dibandingkan dengan GLCM dan Gabor Wavelet yang memberikan persentase keberhasilan dibawah 90\%. Penelitian lain juga dilakukan oleh [4] dengan menggunakan ekstraksi fitur wavelet dan jaringan saraf tiruan Radial Basis Function (RBF) dengan hasil pengenalan iris mata menghasilkan akurasi pengenalan tertinggi sebesar 72,5\%. Menurut penelitian yang telah dilakukan [5] tentang pengenalan iris menggunakan fitur LBP dan LVQ Classifier didapatkan tingkat identifikasi dengan hasil sebesar 99,87\%. Metode LBP banyak digunakan sebagai ekstraksi fitur yang telah dilakukan seperti pada penelitian [6] [7] [8] [9]. Metode LBP memberikan pengaruh yang baik terhadap akurasi pengenalan. Metode LBP tersebut digunakan untuk mengekstraksi ciri tekstur dari iris. LBP menjadi metode ekstraksi fitur yang menjadi pertimbangan. Metode RBF juga telah digunakan untuk melakukan pengenalan. Metode ini termasuk dalam jaringan saraf tiruan. Metode RBF yang digunakan pada penelitian yang dilakukan [10]. Pada penelitian tersebut, selain menggunakan RBF terdapat juga metode Support Vector Machine (SVM) dengan ekstraksi fitur Hadamard Transform. Berdasarkan pengujian yang telah dilakukan peneliti bahwa metode RBF mampu memberikan ukuran kinerja yang optimal. Pada penelitian [11] metode RBF juga digunakan untuk pengenalan iris.

Berdasarkan penelitian yang telah dilakukan, penelitian ini menggunakan LBP sebagai metode ekstraksi fitur dan RBF sebagai metode pengenalan. Pada penelitian sebelumnya metode ekstraksi fitur LBP mampu memberikan pengaruh dalam meningkatkan akurasi jika dibandingkan dengan metode lain dan begitupun metode klasifikasi RBF, hasil pengenalan RBF juga memberikan kinerja dan tingkat akurasi yang baik. Sehingga perlu dilakukannya penelitian mengenai pengenalan iris dengan menggunakan metode ekstraksi fitur LBP dengan klasifikasi RBF.

\section{METODOLOGI PENELITIAN}

Tahapan dalam penelitian ini terdiri dari empat tahap antara lain antara lain studi literatur, analisis dan perancangan, implementasi serta pengujian.

\subsection{Studi Literatur}

Biometrik adalah karakteristik yang dimiliki oleh setiap orang dan merupakan metode untuk pengenalan berdasarkan inherence. Terdapat dua jenis biometrik yaitu berdasarkan karakteristik fisiologis dan karakteristik berdasarkan perilaku. Karakteristik fisiologis adalah karakteristik yang berhubungan dengan bentuk tubuh yang dimiliki oleh seseorang, seperti sidik jari, wajah, iris, geometri tangan dan lainnya, sedangkan karakteristik perilaku berkaitan dengan kebiasaan atau pola perilaku seseorang seperti gaya dalam berjalan, suara atau ritme mengetik. Tidak semua biometrik dapat dijadikan sebagai metode pengenalan, setidaknya terdapat beberapa syarat yang harus dipenuhi oleh biometrik yaitu bersifat universal atau setiap orang memiliki karakteristik tersebut, unik, permanen, dapat diukur secara kuantitatif, tidak mudah dipalsukan, dapat diterima atau sejauh mana orang bersedia menggunakan biometrik tersebut dan memiliki performa akurasi pengenalan yang baik.

\subsubsection{Iris}

Iris adalah diafragma melingkar yang tipis, terletak diantara kornea dan lensa mata manusia serta dibatasi oleh pupil dan sklera. Anatomi mata dapat dilihat pada Gambar 1. Rata-rata diameter iris adalah $12 \mathrm{~mm}$ dengan ukuran pupil yang dapat bervariasi antara 10\% sampai dengan $80 \%$ dari diameter iris. Pembentukan iris dimulai pada bulan ketiga embrio, sedangkan pola iris terbentuk selama tahun pertama kehidupan manusia dan pigmentasi stroma berlangsung selama beberapa tahun pertama. Setiap individu memiliki pola iris yang berbeda dan pembentukan pola sendiri tidak berhubungan dengan faktor genetik individu, hanya pigmentasi pada iris (warna) satu-satunya karakteristik yang didasarkan pada faktor genetik [12][13].

Pada Tahun 1985, dua dokter mata yaitu Leonard Flom dan Aran Safir mengusulkan konsep bahwa tidak ada dua iris yang sama dimiliki oleh manusia [14]. Kemudian pada tahun 1991, John Daugman yang merupakan profesor untuk bidang computer vision dan pattern recognition pada University of Cambridge, mengembangkan sebuah algoritma untuk mengidentifikasi iris mata manusia [15]. Sistem biometrik untuk pengenalan iris mata manusia memiliki kelebihan antara lain yaitu unik dimana iris memiliki pola yang unik jika dibandingkan dengan pola lain, karena tekstur yang dimiliki iris. Contohnya bintik-bintik, korona, garis dan kerutan. Bahkan orang yang kembar sekalipun memiliki pola iris yang berbeda. Pembentukan pola pada iris adalah acak dimana pola tersebut tidak berhubungan dengan faktor genetik, hanya pigmentasi pada iris (warna pada iris) yang merupakan karakteristik yang bergantung pada faktor genetik. Iris juga stabil dimana tekstur iris terbentuk selama masa 
kehamilan dan struktur utama pada iris terbentuk setelah 10 bulan kelahiran. Pola iris stabil sepanjang hidup seseorang [13].

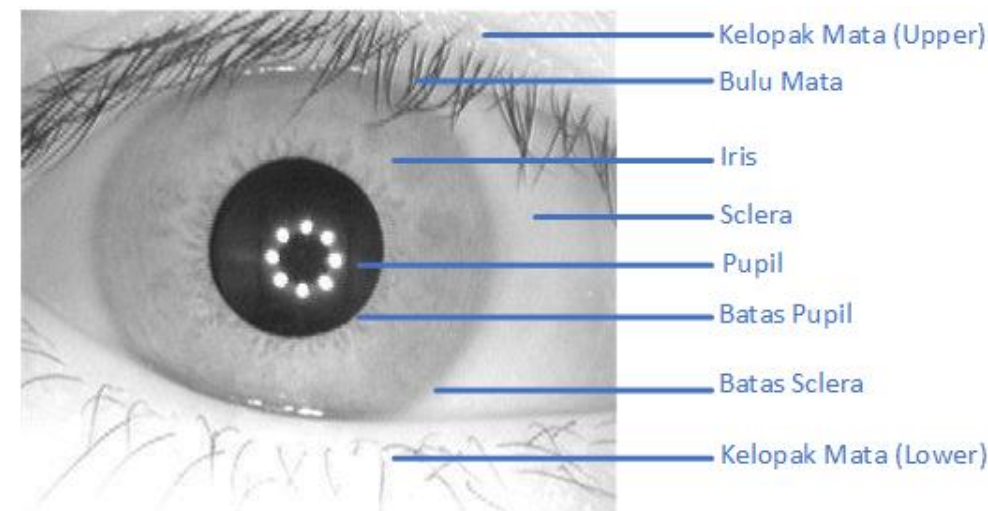

Gambar 1. Anatomi Mata Manusia [16]

\subsubsection{Local Binary Pattern}

Ekstraksi fitur adalah salah satu proses penting dalam pengenalan iris, yang digunakan untuk mendapatkan ciri atau informasi atau fitur dari citra iris. Ciri atau informasi atau fitur yang diperoleh digunakan untuk proses selanjutnya dalam pengenalan iris. Terdapat banyak metode yang dapat digunakan sebagai ekstraksi fitur, pada penelitian ini akan digunakan metode LBP untuk ekstraksi fitur citra iris. LBP atau Local Binary Pattern pertama kali diperkenalkan oleh Timo Ojala, yaitu merupakan metode analisis tekstur dengan menggunakan model statistika dan struktur yang dapat digunakan untuk melakukan klasifikasi berdasarkan tekstur citra. Operator asli LBP berukuran 3 x 3 bekerja dengan delapan piksel tetangga, menggunakan nilai piksel pusatnya sebagai threshold seperti pada Gambar 3 . Perbandingan dilakukan dengan cara membandingkan nilai pusat pixel terhadap nilai pixel disekelilingnya. Jika nilai pixel sekitarnta lebih besar dari nilai pixel pusat, maka pixel diberi nilai 1 dan jika tidak diberi nilai 0 .

\begin{tabular}{|c|c|c|c|c|c|c|}
\hline 58 & 22 & 36 & \multirow{3}{*}{$\stackrel{\text { Treshold }}{\longrightarrow}$} & 1 & 0 & 1 \\
\hline 130 & 30 & 14 & & 1 & & 0 \\
\hline 8 & 20 & 80 & & 0 & 0 & 1 \\
\hline
\end{tabular}

Gambar 2. Operasi LBP Pixel 3 x 3

Setelah itu dilakukan penyusunan delapan nilai biner searah jarum jam atau sebaliknya. Biasanya dilakukan perubahan nilai biner ke dalan nilai desimal, tujuannya untuk menggantikan nilai pada pusat citra. Berikut merupakan ilustrasi dari proses LBP.

a. Mengambil citra iris yang akan digunakan (Dataset CASIA Inverval V4.0)

b. Selanjutnya citra iris tersebut dibagi menjadi beberapa blok dalam bentuk matriks.

c. Kemudian nilai matriks tersebut diubah menjadi nilai threshold dengan membandingkan nilai pusat dengan nilai tetangganya, apabila lebih kecil maka bernilai 0 dan jika lebih besar maka bernilai 1 .

d. Selanjutnya didapakan nilai dari LBP tersebut (seperti pada gambar)

e. Setelah didapatkan ciri dari nilai LBP tersebut, kemudian dilakukan pengenalan, dan kembali lagi ketahap kedua yaitu pembagian menjadi beberapa blok untuk blok-blok selanjutnya.

f. Setelah didapatkan ciri dari semua blok, maka citra iris tersebut dapat dilakukan klasifikasi.

\subsubsection{Radial Basis Function}

Jaringan Syaraf Tiruan (Artificial Neural Network) atau yang biasa yang lebih dikenal dengan JST pertama kali dibuat pada tahun 1943 oleh neurophysiologist Waren McCulloch dan logician Walter Pits. JST merupakan paradigma pemrosesan suatu informasi yang terinspirasi oleh sistem sel syaraf biologi. Jaringan Syaraf Tiruan digunakan untuk memecahkan suatu permasalahan seperti pengenalan pola ataupun klasifikasi. Pada jaringan syaraf tiruan, neuron-neuron akan dikumpulkan dalam lapisan-lapisan yang disebut dengan lapisan neuron, kemudian neuron pada satu lapisan akan dihubungkan dengan lapisan sebelum atau sesudahnya terkecuali lapisan 
input dan lapisan output. Informasi yang diberikan pada jaringan syaraf akan diteruskan dari lapisan ke lapisan lain melalui lapisan input dan lapisan output yang melalui hidden layer. [17] menyatakan bahwa Jaringan Syaraf Tiruan Radial Basis Function merupakan alternatif dari Multilayered feedforward Neural network (MFNNs) telah dikembangkan. Radial Basis Function memiliki algoritma pelatihan yang agak unik karena terdiri atas metode supervised dan unsupervised, dimana metode supervised merupakan metode yang setiap pola yang diberikan ke dalam jaringannya telah diketahui output-nya. Selisih antara pola output aktual (output yang dihasilkan) dengan pola output yang dikehendaki (output target) disebut error, error disini digunakan untuk mengoreksi bobot jaringan. Sedangkan metode unsupervised adalah metode yang tidak membutuhkan target output.

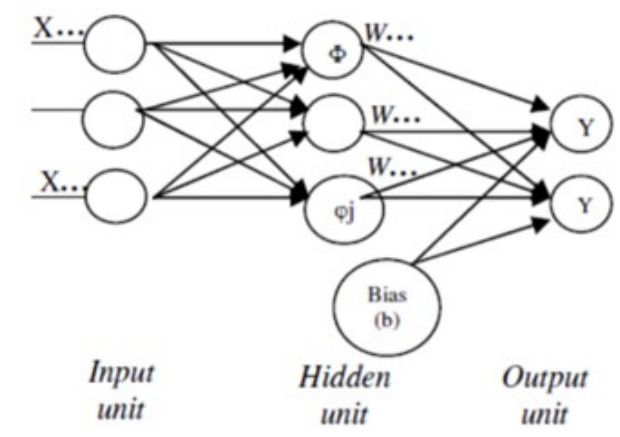

\section{Gambar 3. Jaringan Syaraf Tiruan Radial Basis Function[18]}

Sama halnya dengan algoritma jaringan saraf tiruan yang lain, Radial Basis Function juga memiliki topologi jaringan. Topologi pada RBF terdiri atas input layer, hidden layer, dan output layer. RBF merupakan salah satu Jaringan Saraf Tiruan jenis multilayer yang ditunjukkan pada Gambar 3. Input layer merupakan lapisan yang berperan menerima input berupa vektor. Hidden layer (lapisan yang berada di antara output layer dan input layer) yang merupakan lapisan tersembunyi pada RBF yang hanya ada satu lapisan saja dan dibuat berdimensi tinggi, hal ini mendukung masalah pattern classifier atau klasifikasi pola, dimana semakin tinggi dimensi data, maka semakin akurat hasilnya, dan yang terakhir adalah output layer yang digunakan untuk mengehasilkan output berupa klasifikasi. Berikut Tahapan pada Radial Basis Function :

a. Menyiapkan dataset Citra Iris yang akan digunakan dalam metode ini dataset diambil dari CASIA Interval V4.0

b. Normalisasi data dan penentuan cluster dengan sendirinya akan menghasilkan pusat dari kelompok data.

c. Penentuan bobot dilakukan untuk mendapatkan bobot pada setiap neuronnya. Pada tahap ini dibutuhkan data training dan testing.

d. Salah satu cara untuk mendapatkan parameter yang optimal pada metode RBF adalah dengan menentukan kombinasi yang tepat antara jumlah variabel, dan node pada hidden layer.

e. Meneruskan sinyal input ke hidden layer dan menghitung nilai fungsi aktivasinya pada tiap hidden layer. Serta menyusun matrik Gaussian dari hasil testing dan training

f. Menghitung bobot baru (W) dengan mengalikan pseudoinverse dari matriks Gaussian, dengan vektor target dari data training.

g. Melakukan penghitungan output jaringan dengan metode Ordinary Least Square (OLS), dan melihat ketepatan/akurasi pengelompokan.

\subsection{Analisis dan Perancangan}

Metode yang diusulkan pada penelitian ini adalah pengenalan iris dengan menggunakan Radial Basis Function berdasarkan fitur Local Binary Patern. Urutan proses palatihan dan pengujian yang dilakukan pada penelitian ini dapat dilihat pada Gambar 4. 


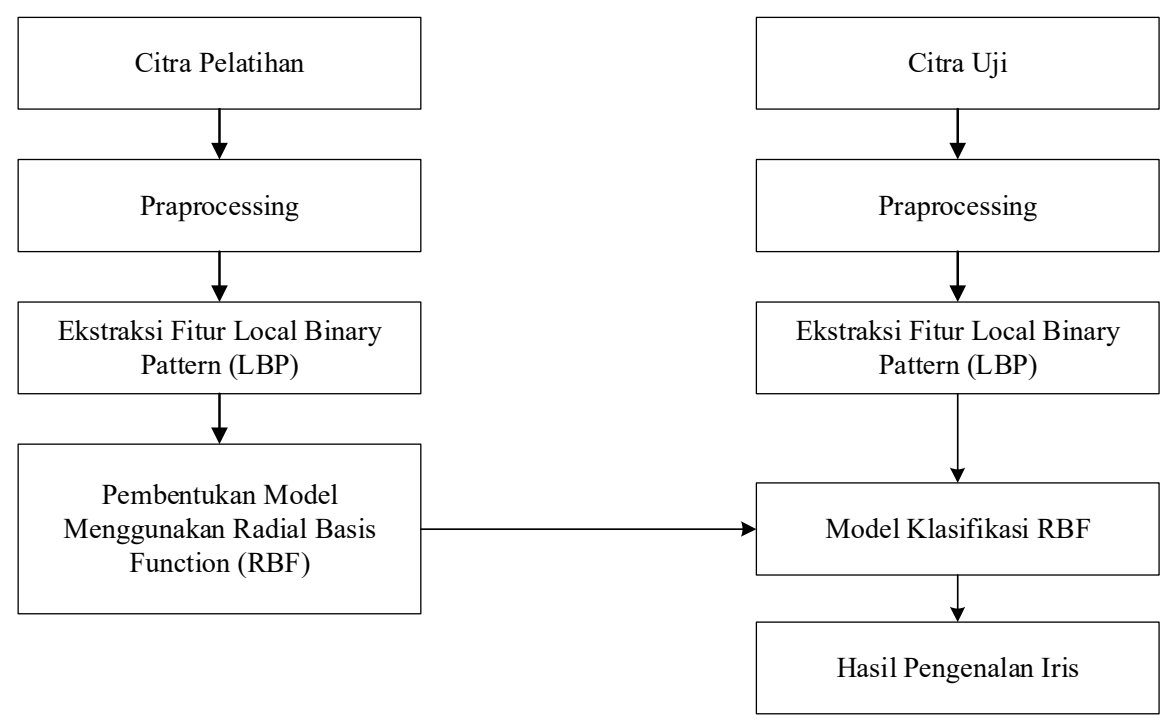

Gambar 4. Proses Pelatihan dan Pengujian Pengenalan Iris

\subsection{Implementasi}

Data yang digunakan dalam penelitian ini berupa citra iris yang didapatkan dari dataset publik Iris CASIA (Chinese Academy of Sciences - Institute of Automation) berupa citra greyscale dengan resolusi 320 x 280 piksel. Total data yang digunakan adalah 210 citra iris dari 15 kelas iris yang masing - masing kelas terdiri dari 14 citra iris baik iris kanan maupun iris kiri. Kemudian dari total data tersebut dikelompokkan menjadi data pelatihan dan data uji. Data pelatihan merupakan data yanag digunakan untuk membentuk sebuah model classifier. Sedangkan data uji adalah data yang digunakan dalam mengukur sejauh mana algoritma classifier sukses dalam melakukan klasifikasi data. Perbandingan data latih dan data uji dalam penelitian ini adalah 180 citra iris digunakann sebagai data pelatihan dan 30 citra iris digunakan sebagai data uji.

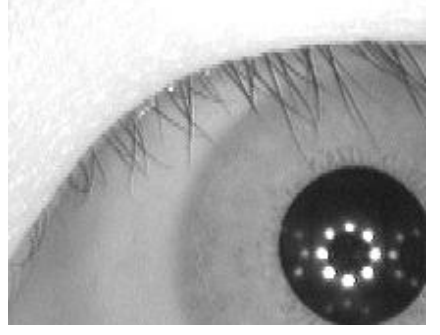

\section{Gambar 5. Citra Iris Kiri Casia Interval V4.0}

Tahapan Preprocessing merupakan suatu proses dalam pengolahan original image sebelum melakukan tahapan selanjutnya yaitu ekstraksi fitur dan pengenalan. Pada penelitian ini tujuan dilakukan preprocessing citra iris adalah untuk menghilangkan noise pada citra iris seperti kelopak mata dan bulu mata. Gambar 5 menunjukkan contoh citra iris sebelum dilakukan praproses.

Gambar 6 menunjukkan tahapan praproses citra iris yang dilakukan. Proses pertama yang dilakukan untuk mendapatkan citra annular iris adalah mendeteksi batas daerah iris dan pupil dengan menggunakan metode Circular Hough Transform dan Canny Edge Detection. Proses dapat dilihat pada Gambar 7. Setalah didapatkan batas iris dan pupil maka daerah pupil akan dihilangkan dapat dilihat pada Gambar 8 dan daerah diluar iris juga akan dihilangkan, Gambar 9 menunjukkan hasil segmentasi citra annular iris. Citra annular iris yang didapatkan akan dilakukan deteksi kelopak dan bulu mata untuk menghilangkan daerah atau noise yang tidak dibutuhkan. 


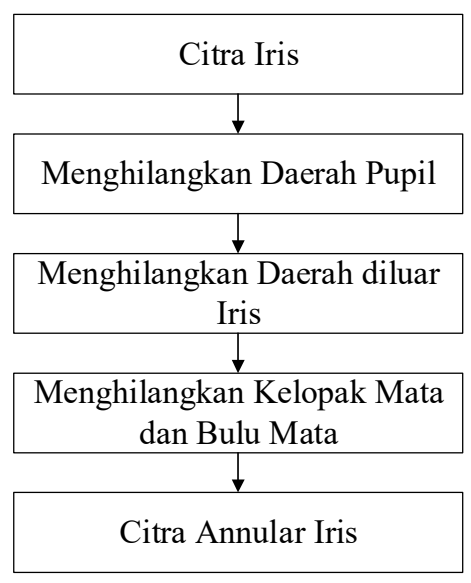

Gambar 6. Tahapan Praprocessing Citra Annular Iris

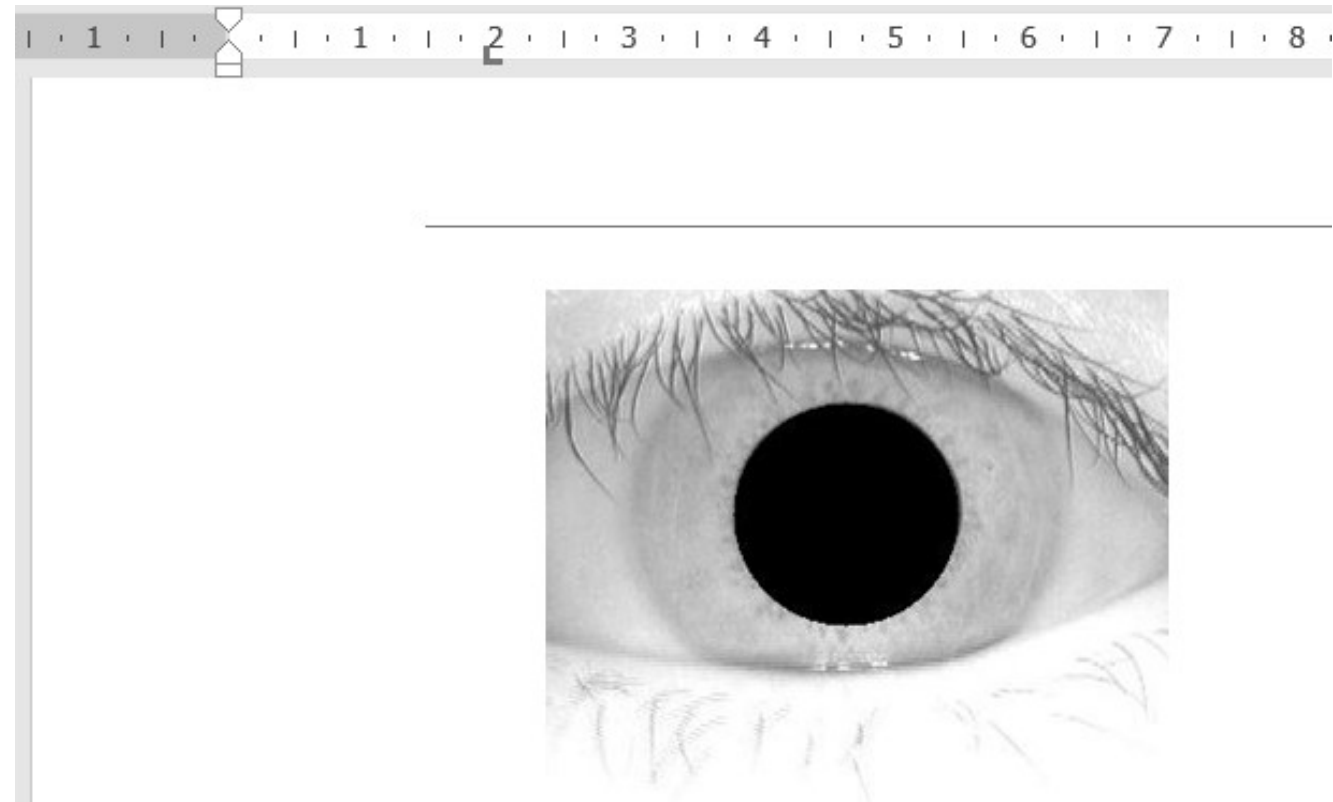

\section{Gambar 7. Citra hasil penghilangan}

\subsection{Tahapan LBP}

Adapun tahapan LBP dapat dilihat pada Gambar 10.

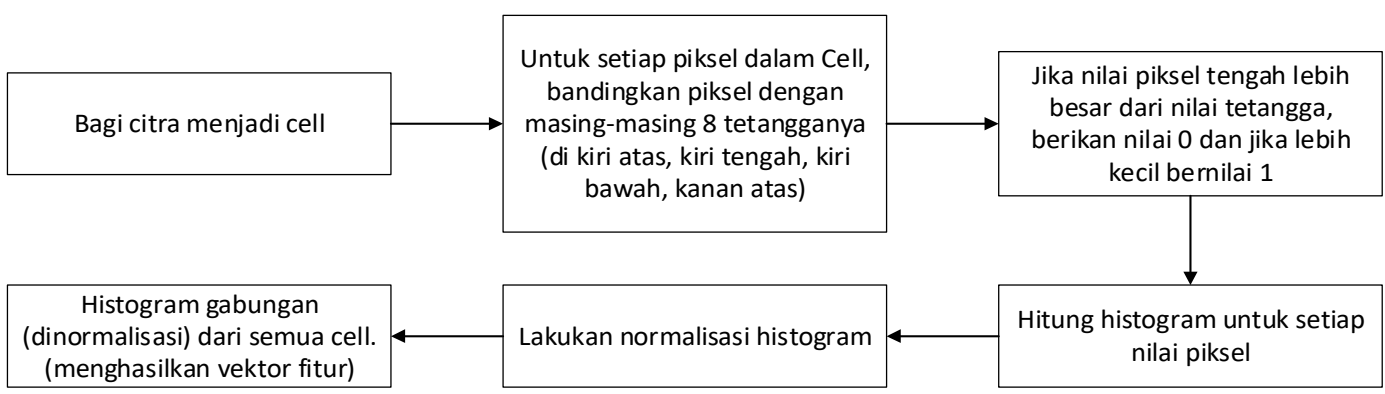

Gambar 10. Proses Ekstraksi Fitur LBP

\subsection{Tahapan RBF}

Tahapan RBF dimulai dengan fitur LBP yang diperoleh dari proses ekstraksi fitur sebelumnya. Dikarenakan terdapat 15 kelas iris maka, pada tahapan ini, RBF akan diatur untuk dapat mengenali 15 
kelas tersebut. Pada proses RBF terdapat parameter SPREAD. Parameter SPREAD merupakan sensitivitas terhadap data. Nilai SPREAD tergantung dari jenis fitur sehingga nilai SPREAD dapat disesuaikan. Proses RBF secara umum dapat dilihat pada Gambar 11.

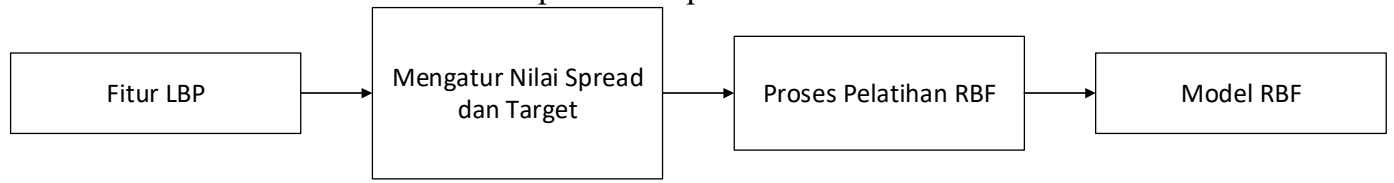

\subsection{Pengujian}

Gambar 11. Proses Training RBF

Pengujian dilakukan untuk mengevaluasi hasil yang diperoleh oleh sistem pengenalan iris. Evaluasi hasil diukur dengan menggunakan confusion matrix seperti pada Tabel 1.

Tabel 1. Confusion matriks

\begin{tabular}{ccc}
\hline \multirow{2}{*}{ Aktual } & \multicolumn{2}{c}{ Dikelompokan sebagai } \\
\cline { 2 - 3 } & + & - \\
\hline+ & True Positive & False Negative \\
& $(\mathrm{TP})$ & $(\mathrm{FN})$ \\
\hline- & False Positive & True Negative \\
& $(\mathrm{FP})$ & $($ TN)
\end{tabular}

Perhitungan akurasi dengan tabel confusion matrix adalah sebagai berikut:

Akurasi $=((\mathrm{TP}+\mathrm{TN})) /((\mathrm{TP}+\mathrm{TN}+\mathrm{FP}+\mathrm{FN}))$

\section{HASIL DAN PEMBAHASAN}

\subsubsection{Skenario Pengujian 1}

Pelatihan dilakukan terhadap 15 kelas iris dengan masing-masing 6 citra iris kiri, sedangkan pengujian terhadap 1 citra iris kiri. Tabel 2 menunjukkan akurasi pengenalan dengan nilai SPREAD yang berbeda-beda. Berdasarkan Tabel 2 dapat diketahui bahwa akurasi pengenalan tertinggi mencapai $53,33 \%$. Nilai SPREAD yang memberikan akurasi pengenalan tertinggi yaitu 10, 20 dan 50. Nilai SPREAD yang berbeda memberikan hasil akurasi yang berbeda. Nilai SPREAD terkait dengan sensivitas data. Pada skenario ini nilai SPREAD yang meningkat akurasi menjadi fluktuatif.

Tabel 2. Akurasi pengenalan iris

\begin{tabular}{ccc}
\hline No. & SPREAD & Akurasi Pengenalan \\
\hline 1 & 10 & $53.33 \%$ \\
2 & 20 & $53.33 \%$ \\
3 & 30 & $46.67 \%$ \\
4 & 40 & $46.67 \%$ \\
5 & 50 & $53.33 \%$ \\
6 & 60 & $46.67 \%$ \\
7 & 70 & $33.33 \%$ \\
8 & 80 & $33.33 \%$ \\
9 & 90 & $46.67 \%$ \\
10 & 100 & $46.67 \%$ \\
11 & 110 & $46.67 \%$ \\
12 & 120 & $46.67 \%$ \\
\hline
\end{tabular}




\subsubsection{Skenario Pengujian 2}

Pelatihan dilakukan terhadap 15 kelas iris dengan masing-masing 6 citra iris kanan, sedangkan pengujian terhadap 1 citra iris kiri. Tabel 3 menunjukkan akurasi pengenalan dengan nilai SPREAD yang berbeda-beda. Berdasarkan Tabel 3 dapat diketahui bahwa akurasi pengenalan tertinggi mencapai 66,67\%. Nilai SPREAD yang memberikan akurasi pengenalan tertinggi yaitu dimulai dari 40 . Nilai SPREAD pada skenario ini relatif stabil. Dengan penambahan nilai SPREAD dimulai dari 40 menunjukkan akurasi yang sama yaitu $66.67 \%$.

Tabel 3. Akurasi pengenalan iris

\begin{tabular}{ccc}
\hline No. & SPREAD & Akurasi Pengenalan \\
\hline 1 & 10 & $60.00 \%$ \\
2 & 20 & $60.00 \%$ \\
3 & 30 & $53.33 \%$ \\
4 & 40 & $66.67 \%$ \\
5 & 50 & $66.67 \%$ \\
6 & 60 & $66.67 \%$ \\
7 & 70 & $66.67 \%$ \\
8 & 80 & $66.67 \%$ \\
9 & 90 & $66.67 \%$ \\
10 & 100 & $66.67 \%$ \\
11 & 110 & $66.67 \%$ \\
12 & 120 & $66.67 \%$ \\
\hline
\end{tabular}

\subsubsection{Skenario Pengujian 3}

Pelatihan dilakukan terhadap 15 kelas iris dengan masing-masing 6 citra iris kiri dan dan 6 citra iris kanan, sedangkan pengujian terhadap 2 citra iris. Tabel 4 menunjukkan akurasi pengenalan dengan nilai SPREAD yang berbeda-beda. Berdasarkan Tabel 4 dapat diketahui bahwa akurasi pengenalan tertinggi mencapai $83,33 \%$. Pada skenario ini, nilai SPREAD yang memberikan akurasi tertinggi yaitu 40 dan 50 . Akurasi yang diperoleh dari skenario ini, menunjukkan peningkatan SPREAD akurasi pada awalnya menaik lalu menurun.

Tabel 4. Akurasi pengenalan iris

\begin{tabular}{ccc}
\hline No. & SPREAD & Akurasi \\
\hline 1 & 10 & $70.00 \%$ \\
2 & 20 & $66.67 \%$ \\
3 & 30 & $73.33 \%$ \\
4 & 40 & $83.33 \%$ \\
5 & 50 & $83.33 \%$ \\
6 & 60 & $80.00 \%$ \\
7 & 70 & $76.67 \%$ \\
8 & 80 & $73.33 \%$
\end{tabular}




\begin{tabular}{ccc}
\hline No. & SPREAD & Akurasi \\
\hline 9 & 90 & $73.33 \%$ \\
10 & 100 & $70.00 \%$ \\
11 & 110 & $70.00 \%$ \\
12 & 120 & $63.33 \%$ \\
\hline
\end{tabular}

\section{KESIMPULAN}

Ekstraksi fitur LBP dan RBF dapat digunakan untuk pengenalan iris. Pengujian dilakukan menggunakan 3 skenario. Pada skenario pertama menggunakan 6 citra iris kiri sebagai citra latih dan akurasi tertinggi mencapai $53,33 \%$. Pada skenario kedua menggunakan 6 citra iris kanan sebagai citra latih dan akurasi tertinggi mencapai $66,67 \%$. Pada skenario terakhir menggunakan 6 citra iris kiri dan 6 citra iris kanan sebagai citra latih menghasilkan akurasi tertinggi $83,33 \%$. Nilai spread menunjukkan hasil yang berbeda-beda. Penelitian lanjutan yang dapat dilakukan selanjutnya yaitu dengan menentukan nilai spread untuk meningkatkan akurasi. Citra latih yang digunakan dapat ditambah untuk proses pelatihan. Skenario-skenario pengujian lain juga dapat dicoba sehingga dapat menemukan akurasi yang lebih baik.

\section{DAFTAR PUSTAKA}

[1] Maimunah and Harjoko, A. 2007. "Sistem pengenalan iris mata manusia dengan menggunakan transformasi wavelet.” Semin. Nas. Apl. Teknol. Inf. 2007, vol. 2007, no. Snati

[2] Harakannanavar, Sunil.S and Puranikmath, I Veena. 2013. "Comparative Survey of Various Iris Recognition." International Conference on Electrical, Electronics, Communication, Computer and Optimization Technique (ICEECCOT), vol. 1, no. 1, pp. 46-58.

[3] Kanchan. S. Bhagat, et al. 2017. "Iris recognition using radon transform and GLCM." 2017 Int. Conf. Adv. Comput. Commun. Informatics, ICACCI 2017, vol. 2017-Janua, pp. 2257-2263

[4] Puspitawati, D.E. et al.2008. "Pengenalan iris mata dengan menggunakan metode wavelet dan jaringan syaraf tiruan radial basis function," Fak. Tek. Inform. Progr. Stud. S1 Tek. Inform.

[5] Rashad, et al. 2011. "IRIS Recognition Based On LBP and Combined LVQ Classifier.". Int. J. Comput. Sci. Inf. Technol., vol. 3, no. 5, pp. 67-78

[6] Nigam, A, et al.2014. "Iris recognition using block local binary patterns and relational measures.". IJCB 2014 - 2014 IEEE/IAPR Int. Jt. Conf. Biometrics

[7] He, Yuqing, et al.2011. "Iris feature extraction method based on LBP and chunked encoding," Proc. - 2011 7th Int. Conf. Nat. Comput. ICNC 2011, vol. 3, pp. 1663-1667.

[8] Kumar, K.Kishore and Pavani, Movva. 2017."LBP based biometrie identification using the periocular region," 2017 8th IEEE Annu. Inf. Technol. Electron. Mob. Commun. Conf. IEMCON 2017, pp. 204-209.

[9] Popplewell, Khary, et al. 2014. "Multispectral iris recognition utilizing hough transform and modified LBP," Conf. Proc. - IEEE Int. Conf. Syst. Man Cybern., vol. 2014-Janua, no. January, pp. 1396-1399.

[10] Khedkar, Mrunal M. and Ladhake, S.A. 2013. "Robust human Iris Pattern Recognition System Using Neural Network Approach,”.

[11] Khedkar, Mrunal M. and Ladhake, S. A.2013 "Neural network based iris pattern recognition system using discrete Walsh Hadamard transform features," Proc. 2013 Int. Conf. Adv. Comput. Commun. Informatics, ICACCI 2013, pp. 388-393.

[12] Daugman, J. 2004. "How iris recognition works?," IEEE Trans Circuits Syst Video Technol, vol. 14, no. 1, pp. 21-30.

[13] Libor, Masek.2007. "Recognition of human iris patterns for biometric identification," J. Eng. Appl. Sci., vol. 54, no. 6, pp. 635-651.

[14] Flom, Leonard and Safir, Aran. 1987. "Iris Recognition System (U.S Patent)," United States Pat.

[15] Daugman, J. 1994. "Biometric Personal Identification System Based On Iris Analysis,".

[16] Devella, Siska. 2019. "Pengenalan Iris Menggunakan K - Nearest Neighbors dengan Ekstraksi Fitur Dicrete Cosine Transform," vol. 02, no. 01, pp. 27-33.

[17] Gupta, Madan M, et al. 2003, Static and Dinamic Neural Network From Fundamentals to Advanced Theory.

[18] Dillak, Rocky Yefrenes, et al.2012. "Penerapan Jaringan Saraf Tiruan Radial Basis Function Pada 
Jurnal SIMETRIS, Vol. 11 No. 1 April 2020

P-ISSN: 2252-4983, E-ISSN: 2549-3108

Diaknosa Danmedical Prescription Penyakit Jantung," Semin. Nas. Inform. 2012 (semnasIF 2012) UPN"Veteran” Yogyakarta, 30 Juni 2012, vol. 2012, no. semnasIF, pp. 115-121. 